\title{
Enhancing Customer Loyalty Through E-Banking Practices
}

\author{
Kajenthiran Konalingam \\ Department of Marketing, University of Jaffna, Sri Lanka. \\ E-mail: Kajentitans@gmail.com \\ Umanakenan Ratnam \\ Department of Commerce, University of Jaffna, Sri Lanka. \\ E-mail: kenanratnam3@gmail.com \\ Achchuthan Sivapalan \\ Department of Commerce, University of Jaffna, Sri Lanka. \\ E-mail: achchu2009@gmail.com \\ Miresh Naveen \\ Department of Commerce, University of Jaffna, Sri Lanka. \\ E-mail: mireshnaveen@gmail.com
}

Received: October 6, 2017 Accepted: October 18, $2017 \quad$ Published: October 25, 2017

doi:10.5296/bms.v8i2.12054ＵRL: https://doi.org/10.5296/bms.v8i2.12054

\begin{abstract}
Enhancing customer loyalty serves as a basic strategy for gaining competitive advantage in the banking industry and enables bankers to make a loyal customer base. The purpose of this work is to propose and empirically investigate a comprehensive mechanism for enhancing customer loyalty to banks via e-banking practices. A questionnaire derived from previous studies and the relevant literature was completed by 472 bank customers in Jaffna city, Sri Lanka. Multiple regression analysis was performed to test hypotheses. The results indicated
\end{abstract}




\section{Macrothink}

Business Management and Strategy ISSN 2157-6068 2017, Vol. 8, No. 2

that customer loyalty was influenced by content \& website layout, privacy \& security, and accessibility. The findings of this paper contribute to previous research by adding to existing knowledge relating to e-banking practices and customer loyalty in banking industries.

Keywords: e-banking practices, customer loyalty and Sri Lanka 


\section{Introduction}

Technological developments particularly in the realm of telecommunication and information technology streamline the banking industry towards success (Anguelov, Hilgert, \& Hogarth, 2004; Goi, 2015). In this context, e-banking practices, which is concerned with the automated delivery of new and traditional banking products and services directly to customers through electronic and interactive communication channels become the prominent level to facilitate the customers (Sohail \& Shanmugham, 2003; Srinivasan, Anderson, \& Ponnavolu, 2002; Vijayan \& Shanmugam, 2015). In line with above discussion, the e-banking practices ensure the compelling advantages that it offers greater flexibility, enhanced market outreach, lower cost structures, faster transactions, broader product lines, greater convenience and customization (Alhinai, Albadi, Alshihi, \& Al-Gharbi, 2013). Due to this, banking institutions has already started to focalize on e-banking practices as the core-competence to create the customer value (Angelakopoulos \& Mihiotis, 2011; Bauer, Hammerschmidt, \& Falk, 2005; Mobarek, 2007; Shahriari, 2014; Srinivasan et al., 2002). In the supportive view, Armstrong, Adam, Denize, and Kotler (2014) suggest that, marketers need to develop their strategic marketing efforts for enhancing customer loyalty to their organization and to their brands by enriching superior customer value.

For all intents and purposes the growth of e-banking facilities enhance the customer loyalty through the customer value creation (Reichheld \& Sasser, 1990). Therefore e-banking practices related to customer loyalty have become increasingly interested in issues that researchers and practitioners have dealt with in recent years (Floh \& Treiblmaier, 2006). Besides, focusing on the relationships between customers and banks over the internet, there is still a lack of studies which analyze the formation of both concepts (Casaló, Flavián, \& Guinalíu, 2008; Ribbink, Van Riel, Liljander, \& Streukens, 2004). Numerous studies have been undertaken to examine issues in the wider context of e-banking practices and consumer intention, customer satisfaction and customer preferences, even though comprehensive research in the area of e-banking practices and customer loyalty in the specific context of Sri Lanka has been rather limited.

Above discussion strained that the main purpose of this study to empirically investigate the influence of e-banking practices on customer loyalty. Hence, this study significantly contributes to the literature relating to e-banking practices and customer loyalty. Furthermore, the findings of this study ensures the useful practical implications for the banks and financial institutions to enhance customer loyalty and customer retention by refining their e-banking infrastructure. As a result, the findings of this study may strengthen e-banking services and customer loyalty of existing banks and those who are planning to provide the services in future.

\section{Literature Review}

In this section, we review the relevant literature on the concept of e-banking practices, customer loyalty and the main antecedents of the e-banking practices. 


\subsection{E-banking Practices}

Increased usage of digital technologies and real-time ICT capabilities already have changed the platform for customers to adopt the e-banking practices (Nudurupati, Tebboune, \& Hardman, 2016). Therefore most of the banks and financial intermediaries are adopting e-banking practices to enable a superior baking services to their customers. In line with above fact, internet banking service delivers the customers to carry out a range of banking activities electronically at any time and place with low handling cost (Amin, 2016; Angelakopoulos \& Mihiotis, 2011; Narayanasamy, Rasiah, \& Tan, 2011; Yoon \& Steege, 2013). To be precise, the usage of internet banking has become one of the most important element in e-commerce environment (Wang, Wang, Lin, \& Tang, 2003).

As a result, previous researchers have empirically found that e-banking practices has an influence on customers to access internet banking with a higher degree of convenience which offers 24/7 services. (Amin, 2016; Floh \& Treiblmaier, 2006; Johnson \& Marakas, 2000a; Karjaluoto, Mattila, \& Pento, 2002; Lassar, Manolis, \& Lassar, 2005; Mukherjee \& Nath, 2003; Pikkarainen, Pikkarainen, Karjaluoto, \& Pahnila, 2004; Poon, 2007; Rotchanakitumnuai \& Speece, 2004; Tan \& Teo, 2000; Venkatesh \& Davis, 1996). Therefore, today, several financial institutions are endeavoring to emphasize customer-oriented services via internet. In this juncture, it is crucial to implement new banking services in order to develop and keep better relationships with customers. Alhinai et al. (2013) listed many benefits that e-banking can offer, such as real-time services, online banking services, account to account transfer, demand draft or request for a cheque book, finding out the latest account balance, getting detailed account statements, making inquiry on account statement, paying their credit card dues directly to the bank through the net and paying utility bills. Besides, the e-banking provides faster, easier and more reliable services to customers (Aladwani, 2001).

\subsection{Customer Loyalty}

Organizations in this contemporary world use customer loyalty as a core consequence to gain competitive advantage over its rivals. Therefore, a loyal customer is considered as a valuable competitive asset for any organizations in the globalized level (Dekimpe, Steenkamp, Mellens, \& Abeele, 1997; Flavián, Guinalíu, \& Gurrea, 2006; Keating, Rugimbana, \& Quazi, 2003). In this supportive way, Kotler and Armstrong (2013) suggest that the cost of attracting a new customer may be five times the cost of keeping a current customer delighted. Moreover, It is very critical to create loyalty among customers of the service providing organizations like banking and financial institutions (Casaló et al., 2008; Kheng, Mahamad, Ramayah, \& Mosahab, 2010). Banks and other financial intermediaries recognize that, the information technology has already become an important pillar to create loyalty among customers (Bukhari \& Kazi, 2016; S.-C. Chen, 2015). Therefore, the banks introduced, E-banking as the newest delivery channel for banking services to create customer loyalty (Mobarek, 2007).

More than ever before, strong competition, fragmentation of markets, short life cycles of products and increasing customer awareness and complexity are the prominent challenges to 
the banking sector (Taleghani, Gilaninia, \& Mousavian, 2011). However, many customers are highly enthusiastic about internet banking and its services due to its self-service banking facilities (Rotchanakitumnuai \& Speece, 2003; Sarel \& Marmorstein, 2003). Hence, Scholars initiated to examine the influence of e- banking practices on customer loyalty (Al-Alak, 2014; Amin, 2016; Andaleeb, Rashid, \& Rahman, 2016; Auta, 2010; Kaur \& Kiran, 2015; Masoud \& AbuTaqa, 2017; Mohsin Butt \& Aftab, 2013; Nupur, 2010). At this juncture, it is crucial to implement new banking services in order to develop and keep better relationships with customers. Hence building up competitive predominance almost depends on customers' loyalty with banking service (Srinivasan et al., 2002).

There are several studies focusing on the relationships among customer satisfaction, customer loyalty and e-banking practices over the internet in the western perspective (Adapa \& Cooksey, 2013; Casaló et al., 2008; Gorgani, 2016; Petzer et al., 2017; Thakur, 2014). But in a developing country like Sri Lanka, there is still a lack of studies that analyse the formation of above concepts. Whilst, there is a huge need for this kind of study in the northern part of Sri Lanka in the post war context, the aim of this study is to examine the influence of ebanking practices on customer loyalty. Moreover the finding of this study helps the banks and financial institutions which are operating in this region to formulate the appropriate strategies to build customer loyalty in the context of electronic banking.

\subsection{Underpinning Theory of Technology Acceptance Model (TAM)}

The theory of Technology Acceptance Model (TAM) is a widely accepted model in the realm of Information Technology. TAM was developed by Davis (1989) to theorize the usage behavior of computer technology. The TAM was adopted from another popular theory called Theory of Reasoned Action (TRA) (Ajzen \& Fishbein, 1975), which explains the relationship between user's beliefs, attitudes and intentions. The TAM indicates that, user acceptance can be explained by two beliefs as perceived usefulness and perceived ease of use (Chuttur, 2009; Dwivedi, Rana, Jeyaraj, Clement, \& Williams, 2017). Within the last two decades, the TAM has been tested, refined, and extended to better understand the intention to use technology. Therefore, researchers have predominantly used the TAM to understand the e-banking practices (Al-Qeisi, Dennis, Alamanos, \& Jayawardhena, 2014; Diatmika, Irianto, \& Baridwan, 2016; Martins, Oliveira, \& Popovič, 2014; Park, Baek, Ohm, \& Chang, 2014; Pikkarainen et al., 2004). Besides, TAM offered a strong and simple explanation of the acceptance of technology and the behavior of the technology users (Davis, 1989) and it predicts the usage behavior of a new technology by its users (Venkatesh \& Davis, 2000). 


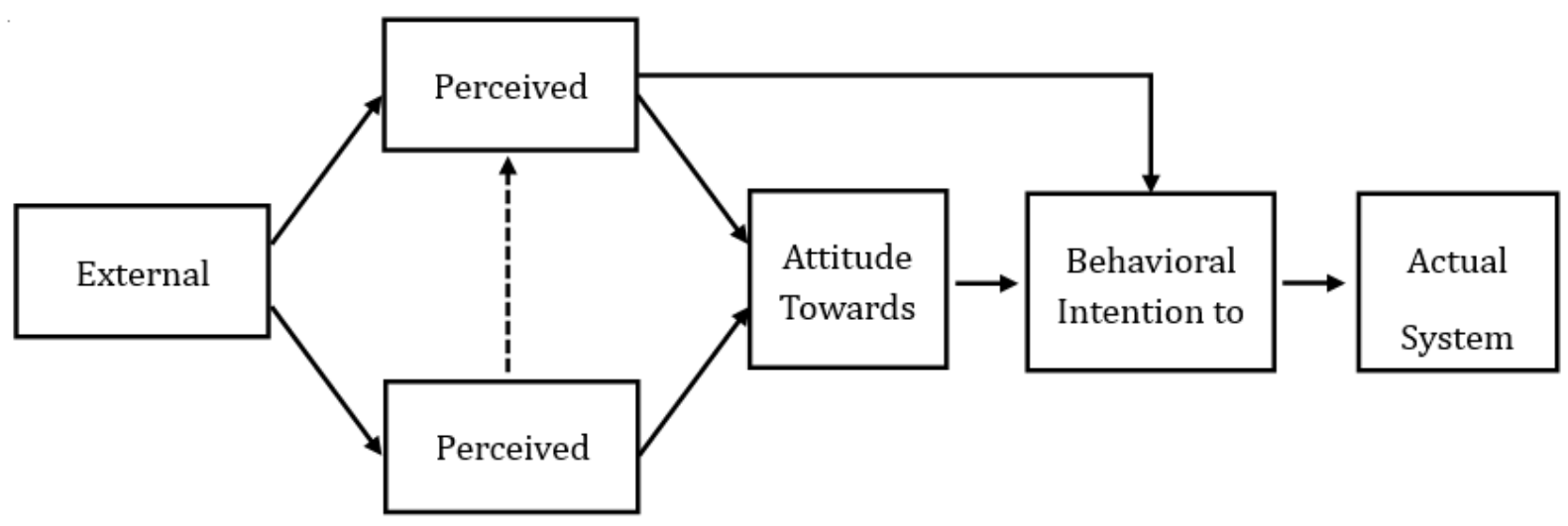

Figure 1. Technology Acceptance Model (TAM)

Source: Theory of Technology Acceptance Model (TAM) (Davis, 1989)

Davis (1989), believes, there were two foremost dimensions in technology users' acceptance specifically, perceived ease of use and perceived usefulness. Perceived ease of use is a person's persuasion that the usage of an information system technology was easy and unambiguity. Perceived usefulness is the degree of a person's belief that, the usage of an information system technology could enhance performance and cost effective.

Based on the aforesaid model, perceived ease of use and perceived usefulness influence attitude towards using, which in turn predicts the intention towards using the system. To this end, intention predicts the actual usage of system (Agarwal, Sambamurthy, \& Stair, 2000; Chau, 2001; Hong, Thong, \& Wai-Man Wong, 2002; Johnson \& Marakas, 2000b; Pikkarainen et al., 2004; Poon, 2007; Venkatesh \& Davis, 1996; Wang et al., 2003) . Therefore the researchers adopted this model to assess the e-banking practices. Besides the basic TAM model, the e-banking practices could be examined via five dimensions such as, content and website layout, speed of delivery, privacy and security, convenience and accessibility (Ahmad \& Al-Zu’bi, 2011; Gorgani, 2016; Kazi, 2013; Poon, 2007). In accordance with the above discussion, this study aimed to find out and add references to the influence of perceived ease of use and perceived usefulness on attitude toward using and on actual usage of e-banking among the banking customers.

\subsection{The Influence of E-Banking Practices on Customer Loyalty}

Loyal customers are now viewed as the source for company's profit, growth and market share (Ariff, Yun, Zakuan, \& Jusoh, 2012; Yuen \& Chan, 2010). Banking industry has moved instantly to deploy and offer new banking services via e-channels for customers and in consequence the e-banking services have boomed promptly (Kaur \& Kiran, 2015). Interestingly, researchers focus on the concept of loyalty within the context of electronic commerce, or e-loyalty. (Toufaily, Ricard, \& Perrien, 2013). Today, several financial institutions are endeavoring to emphasize customer-oriented services. At this juncture, it is crucial to implement new banking services in order to develop and keep better relationships 
with customers. However Luarn and Lin (2003) endorse that the loyalty is almost identical to those of traditional loyalty from an online service provider. In support of this view, Ariff et al. (2012) suggest building loyalty in internet banking is prominent for banks to ensure high rate of customer retention. Further, it is recognized that e-banking practices aligned with higher customer satisfaction, which directs to relationship an association with greater revenues, increased cross-sell rations, higher customer loyalty, retention and bigger market share (Amin, 2016). E-banking system is one of best examples of innovative technologies that have a great potential to create a win-win scenario for both customers and businesses (Alhinai et al., 2013). The foregoing discussion indicates an association between e-banking practices and customer loyalty, so the following hypothesis is formulated:

$\mathbf{H}_{1}$ : e-banking practices positively affect customer loyalty

\subsection{The Dimensions of E-Banking Practices and Their Influences on Customer Loyalty}

\subsubsection{Content and website layout}

e-banking practices refers to the consumers overall evaluation and judgment of the excellent and quality of electronic services offering in the virtual marketplace (Santos, 2003). In this way, firms can gain abundant benefits from well-designed websites (Al-Qeisi et al., 2014). Therefore the contents on website is one of the major factors influencing e-banking practices (Casaló et al., 2008; Poon, 2007; Sohail \& Shanmugham, 2003). Generally, proper navigational attributes and search facilities in website contents lead to higher level of interaction, which tap the customers mind favourably to use the system (Pikkarainen et al., 2004; Sohail \& Shanmugham, 2003). Moreover, intellectual capacity of the contents and tasks in a website help to reduce possible errors, which is a key aspect of e-banking services (Casaló et al., 2008; Jayawardhena \& Foley, 2000; Pikkarainen et al., 2004). In this context the content and web site layout facilitates efficient and effective delivery of e-banking services Therefore it may influence the levels of customer loyalty. As a consequence, we formulate the following hypothesis:

$\mathbf{H}_{1 \mathbf{a}}$ : Content and website layout affect customer loyalty to e-banking services.

\subsubsection{Speed of Delivery}

Customers are particularly interested in the speed with which a service is offered or delivered because speed of e-transactions flow is critical to user satisfaction of using e-banking services (Liao \& Cheung, 2002; Poon, 2007). Besides that, Johnston (2011) illustrates that certain actions, such as increasing the speed of processing information and customers, are likely to have an effect on customer satisfaction and loyalty. In which, time saving may be the driving force of customer loyalty in the e- banking scenario. (Gerrard, Barton Cunningham, \& Devlin, 2006; Liao \& Cheung, 2002; Polasik \& Piotr Wisniewski, 2009; Poon, 2007; Siu \& Mou, 2005). In line with above facts, speed of delivery has substantial effects on customer loyalty. Therefore, it is expected that,

$\mathbf{H}_{1 \mathbf{b}}$ : Speed of delivery affect customer loyalty to e-banking services. 


\subsubsection{Privacy and Security}

The past researches suggest that privacy and security is an important factor that affect users' intention to adopt e-based transaction systems (Ahmad \& Al-Zu'bi, 2011; Y. H. Chen \& Barnes, 2007; Gerrard \& Barton Cunningham, 2003; Gorgani, 2016; Poon, Yong, \& Lam, 2008; Sohail \& Shanmugham, 2003; Wu \& Chang, 2005). Privacy and security denote the proper authorization and confidentiality of customer's information and transactions in a bank (Katsikas, Lopez, \& Pernul, 2005; Kolsaker \& Payne, 2002; Liao \& Cheung, 2002). Therefore customer preference and confidence on e-banking would also largely depend on how the banks would deal with any erroneous transactional and security concerns that may occur during online banking (Polasik \& Piotr Wisniewski, 2009; Sohail \& Shanmugham, 2003). To this end, it strains that, privacy and security in e- banking services motivate the customers to engage in e- banking services (Floh \& Treiblmaier, 2006; Lallmahamood, 2007). From the discussion above, it can be assumed that there might be an impact of privacy and security on customer loyalty. Therefore, in this study, we propose that:

$\mathbf{H}_{1 \mathbf{c}}$ : Privacy and security positively affect customer loyalty to e-banking services.

\subsubsection{Convenience}

It has been suggested that convenience is one of the most beneficial features of e-banking (Daniel, 1999; Kazi, 2013; Liao \& Cheung, 2002; Usman \& Usman, 2012). Because e-banking provides a higher degree of convenience that enables customers to access e-banking services at all times that is 24/7 access (Lichtenstein \& Williamson, 2006) and any places it could never be in traditional banking (Wan, Luk, \& Chow, 2005). E-banking is more convenience for people to pay their utility bills, check balances, transfer funds, apply for auto loans and mortgages, and use other complementary services at the tip of a finger anytime from anywhere (Kazi, 2013; Ramsaran, 2003; Yu \& Fang, 2009). Therefore from the viewpoint of the consumers, the decision to use e-banking is frequently motivated by convenience and efficiency (Bruno, 2003; Polasik \& Piotr Wisniewski, 2009). As a result, the preceding discussion indicates an influence of this e-banking dimensions on customer loyalty and this discussion also suggests that, convenience has an effects on customer loyalty. Therefore, it is hypothesized:

$\mathbf{H}_{1 \mathrm{~d}}$ : Convenience affect customer loyalty to e-banking services.

\subsubsection{Accessibility}

In our study we focus on the accessibility of information as ease of access to electronic banking applications. Accessibility is the one of the major driver in commercial use of the web which allows to access the information more easily (Rotchanakitumnuai \& Speece, 2004). Accessibility defines as the ability of users to access information and services from the web site (Ahmad \& Al-Zu'bi, 2011). Furthermore, easy access encourages the customers to engage in e- banking services without frequent delay and frustration (Rotchanakitumnuai \& Speece, 2004). In addition, banks should concentrate on the investment in Information 
technology infrastructure to make the proper layout of website and facilitate the customers to assess the information simply (Lederer, Mirchandani, \& Sims, 2001). Moreover, Sadeghi and Heidarzadeh Hanzaee (2010), Poon et al. (2008), Casaló et al. (2008), and Liébana-Cabanillas, Munoz-Leiva, and Rejón-Guardia (2013), express that accessibility is advantageous for attaining user satisfaction and engagement in the adoption of electronic banking. In this sense, we establish the following hypothesis:

$\mathbf{H}_{1 \mathbf{e}}$ : Accessibility affect customer loyalty to e-banking services.

\subsection{Framework of this Study}

This study proposes a framework, which is depicted as follows:

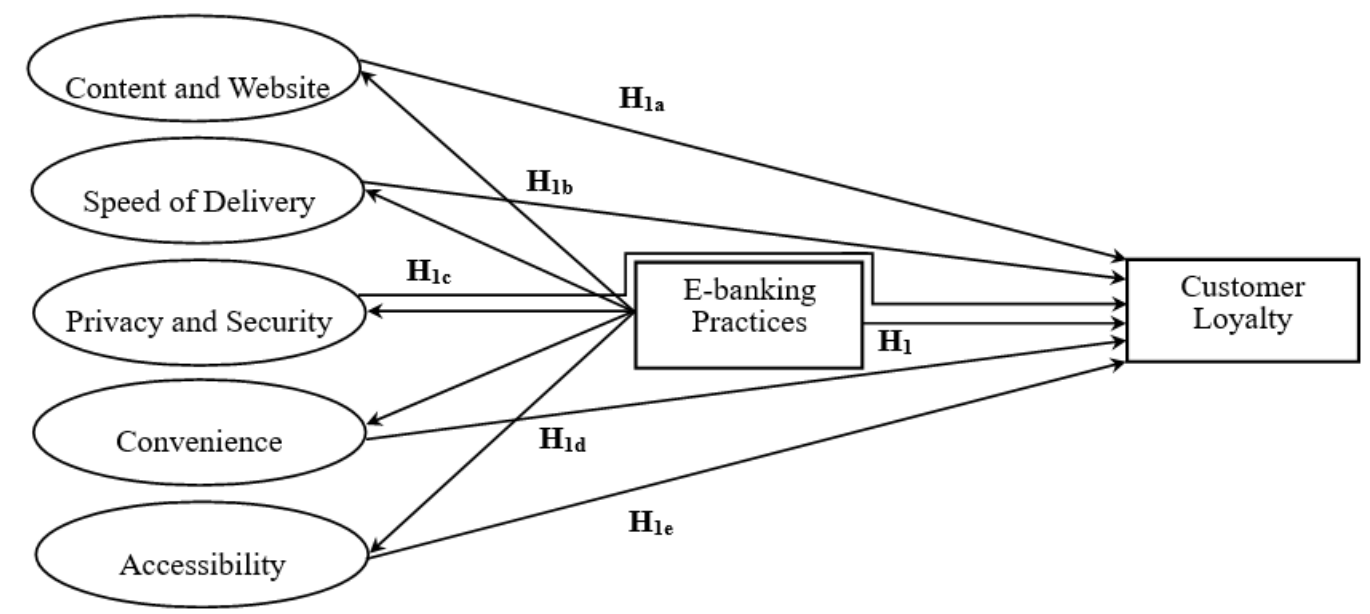

Figure 2. Frame work of this Study

\section{Methods}

\subsection{Sample and Survey Administration}

Our research population consist all the customers of selected banks which are operating in Jaffna city, Sri Lanka. Such as Bank of Ceylon, People's Bank, Commercial Bank, Hatton National Bank, Sampath Bank, Nation Trust Bank, and Cargills Bank. E-banking service in Sri Lanka is presently being offered to two sets of clients, namely, individual customers and business clients. This research mainly focused on Commercial banks' individual customers as the target population in Jaffna city. Therefore, the sample for this study comprised customers who have an account at above Commercial banks in this city. Participants were students, Government and private sector employers and businessman. In this population private sector commercial banks were considered. Systematic quasi-random sampling was adopted to recruit participants for this research. Whilst, causal research approach under the conclusive research design was used in this study by the quantitative way to find out the impact of ebanking practices on customer loyalty. For that purpose, the paper-based surveys were distributed to 550 customers, from which 472 were completed and returned. Of these, 84 surveys had missing data, so they were discarded. Table I presents the demographic 
characteristics of respondents.

\subsection{Measures and Instrument Development}

A paper based survey instrument was developed from previous validated scales that were adapted for the purpose of this study. The scales of e-banking practices included 28 items under the five dimensions: content and website layout, speed of delivery, privacy \& security, convenience and accessibility. This means that, contents \& website layout, was operationalized using six items; speed of delivery, using five items; privacy \& security, using six items; convenience using six items and accessibility, using six items. So these 28 items are adopted from Poon (2007) and customer loyalty was measured with six items, of which the first two were adopted from Lin and Wang (2006) and other four taken from Casaló et al. (2008). The questionnaire has been slightly modified without changing the original contents as it translated into local language to ensure suitability for the research context and it mainly consisted two sections. Section A consists of personal profile of the respondents and section B consists of 34 statements relating to the dimensions of e-banking practices and customer loyalty. A seven-point Likert type scale anchored at one for "strongly disagree" and seven for "strongly agree" was used for items operationalizing all the constructs.

Table I. Demographic profiles of the respondents $(n=388)$

\begin{tabular}{lll}
\hline Category & $N$ & $\%$ \\
\hline Type of Account & & \\
Saving & 287 & 74.0 \\
Current & 101 & 26.0 \\
Gender & & \\
Male & 216 & 55.7 \\
Female & 172 & 44.3 \\
Age & & \\
Below 20 & 16 & 4.1 \\
$21-30$ & 277 & 71.4 \\
$31-40$ & 61 & 15.7 \\
$41-50$ & 25 & 6.4 \\
Above 50 & 9 & 2.3 \\
Profession & & \\
Student & 83 & 21.4 \\
Businessman & 137 & 35.3 \\
Employee in Private/Government Sector & 168 & 43.3 \\
Monthly Individual Income & & \\
Below LKR. 25000 & 97 & 25.0 \\
LKR. 25000 - LKR. 50000 & 207 & 53.4 \\
Above LKR 50000 & 84 & 21.6 \\
\hline
\end{tabular}


To ensure content validity, the survey instrument was vetted by four academics with expertise in the discipline of Marketing, Banking \& Finance. The survey instrument, originally written in English, was translated into Tamil, the respondents' mother tongue. The survey instrument was translated back into English and was cross-checked by two other bilingual researchers to ensure the reliability and validity of translation. The respondents had the option of responding to either the English or Tamil language survey based on their language proficiency. The survey instrument was pretested with eight regular customers of the banks. Based on their feedback, some minor changes were incorporated into the wording and format of the survey instrument.

\section{Analysis and Results}

\subsection{Reliability and Validity Analysis}

In order to ensure the internal consistency of the measure, a reliability test was conducted using Cronbach's alpha, which was higher than 0.70, indicating strong internal consistency (Creswell, 2005; Hair Jr, Black, Babin, Anderson, \& Tatham, 2010). This suggests that the items concerned adequately measure a single construct for each tested variable (content and website layout, speed of delivery, privacy and security, convenience, accessibility and customer loyalty). Whilst, the Overall Cronbach alpha value was 0.843 . Reliability analysis for each construct are shown in Table II. Also, the test indicated the mean value (5.60 to 6.00) with the standard deviation (0.46 to 0.67).

Table II. Reliability Analysis

\begin{tabular}{lc}
\hline Construct & Cronbach's Alpha \\
\hline Content \& Website Layout & 0.812 \\
Speed of Delivery & 0.823 \\
Privacy \& Security & 0.812 \\
Convenience & 0.823 \\
Accessibility & 0.833 \\
Customer Loyalty & 0.799 \\
\hline
\end{tabular}

At the same time, researchers performed KMO and Bartlett's test to accurately assess the construct validity for each measurement item. Based on Table III, the KMO measure of sampling adequacy is more than 0.6 (0.837), which indicates sufficient inter-correlations (Pallant, 2007), whereas the Bartlett's Test of Sphericity is significant at level 0.01 (Chi-square $=882.153$ ). Both results indicating that the constructs are in validity (Heppner \& Heppner, 2004; Sanzo, Santos, Vázquez, \& Álvarez, 2003). 
Table III. KMO and Bartlett's Test

\begin{tabular}{|c|c|c|}
\hline \multicolumn{2}{|c|}{ Kaiser-Meyer-Olkin Measure of Sampling Adequacy. } & 0.837 \\
\hline \multirow{3}{*}{ Bartlett's Test of Sphericity } & Approx. Chi-Square & 882.153 \\
\hline & df & 15 \\
\hline & Sig. & .000 \\
\hline
\end{tabular}

Besides, Skewness and kurtosis values of a data distribution are widely applied to determine normality of a dataset (George \& Mallery, 2003; Joanes \& Gill, 1998; Kim, 2013). In this method, normality of a data distribution is assumed, if statistical values of skewness or kurtosis are within the value \pm 2.56 (Hair Jr et al., 2010; Tabachnick \& Fidell, 2007). Therefore Skewness and kurtosis values of each construct are an additional evidence of normal distribution and we can come to the conclusion that the data among all the constructs are normally distributed. In addition the Pearson correlation coefficient presented to explain the relationship as well as the statistical significance between the factors (see the Table IV: Descriptive statistics and Correlation matrix for study variables). The results reveal that most of the constructs are significantly correlated with each other, the correlation ranging from 0.437 to 0.707 . It proved all the associations were found to be significant at $99 \%$ level and there were positive correlations among all the constructs of e-banking practices and customer loyalty.

Table IV. Descriptive statistics and Correlation matrix for study variables

\begin{tabular}{|c|c|c|c|c|c|c|c|c|c|c|c|}
\hline Construct & $M$ & $S D$ & SKE & KUR & 1 & 2 & 3 & 4 & 5 & 6 & 7 \\
\hline 1. Content \& & 5.87 & 0.61 & -1.05 & 2.25 & 1 & & & & & & \\
\hline \multicolumn{12}{|l|}{ Layout } \\
\hline 2. Speed of Delivery & 5.60 & 0.60 & -0.06 & -0.09 & $.464^{* *}$ & 1 & & & & & \\
\hline 3. Privacy \& Security & 5.89 & 0.60 & -0.79 & 1.29 & $.483^{* *}$ & $.506^{* *}$ & 1 & & & & \\
\hline 4. Convenience & 6.00 & 0.58 & -0.86 & 1.24 & $.417^{* *}$ & $.485^{* *}$ & $.606^{* *}$ & 1 & & & \\
\hline 5. Accessibility & 5.68 & 0.67 & -1.22 & 2.33 & $.435^{* *}$ & $.364^{* *}$ & $.381^{* *}$ & $.337^{* *}$ & 1 & & \\
\hline 6. E-banking Practices & 5.81 & 0.46 & -0.66 & 1.40 & $.750^{* *}$ & $.749^{* *}$ & $.792^{* *}$ & $.752^{* *}$ & $.691^{* *}$ & 1 & \\
\hline 7. Customer Loyalty & 5.82 & 0.67 & -1.02 & 1.28 & $.649^{* *}$ & $.460^{* *}$ & $.489^{* *}$ & $.437^{* *}$ & $.589^{* *}$ & $.707^{* *}$ & 1 \\
\hline \multicolumn{12}{|c|}{ Note: **. Correlation is significant at the 0.01 level } \\
\hline \multicolumn{3}{|l|}{$M=$ Mean,$S D=$ Std. Deviation, } & $S K E=S k$ & $s$ and & \multicolumn{3}{|c|}{$K U R=$ Kurtosis } & & & & \\
\hline
\end{tabular}

\subsection{Test of Multi-Collinearity}

Test of normality of the data, and non-existence of Multi-Collinearity is an important assumption, generally which is done before conducting the correlation and regression 


\section{I Macrothink}

(Santhapparaj \& Alam, 2005). As stated by Ahsan, Abdullah, Fie, and Alam (2009), there are two major methods were employed in order to determine the presence of multi-collinearity among independent variables. These methodologies involved calculation of both a Tolerance test and Variance Inflation Factor (VIF) (Ahsan et al., 2009; Kleinbaum, Kupper, \& Muller, 1988).

Table V. Test of Collinearity

\begin{tabular}{lll}
\hline \multirow{2}{*}{ Construct } & \multicolumn{2}{l}{ Collinearity } \\
\cline { 2 - 3 } & Tolerance & VIF \\
\hline Content \& Website Layout & .647 & 1.545 \\
Speed of Delivery & .639 & 1.565 \\
Privacy \& Security & .533 & 1.875 \\
Convenience & .580 & 1.723 \\
Accessibility & .755 & 1.325 \\
\hline
\end{tabular}

As can be seen from the Table V, none of the Tolerance levels is < or equal to 1 and VIF values are perfectly below 5. It can be seen clearly that VIF range between 1.325 and 1.875 values which are well-below five. Thus, the measures selected for assessing independent variables in this study do not reach levels indicate of multi-collinearity.

\subsection{Regression Analysis}

After examining the multicollinearity and normality test for each aspect of the e-banking practices, the multiple regression analysis was performed in order to predict the significant impact of e-banking practices and its dimension on customer loyalty. Generally, regression analysis is used to answer the question as what extent independent variables influence on the dependent variable (Heppner \& Heppner, 2004; Oly Ndubisi, 2007).

In this context, research question and hypotheses were tested via multiple regression analysis and the results of the regression analysis and hypotheses testing are summarized in Table VI.

Table VI. Regression Analysis and Hypotheses Testing

\begin{tabular}{|c|c|c|c|c|}
\hline Construct & $\begin{array}{l}\text { Coefficients } \\
(\beta)\end{array}$ & t-value & Sig. & Conclusion \\
\hline Content \& Website Layout & .398 & 9.447 & 0.000 & $\mathrm{H}_{1 \mathrm{a}}$ : Accepted \\
\hline Speed of Delivery & .077 & 1.815 & 0.070 & $\mathrm{H}_{1 \mathrm{~b}}$ : Rejected \\
\hline Privacy \& Security & .092 & 1.988 & 0.048 & $\mathrm{H}_{1 c}$ : Accepted \\
\hline Convenience & .066 & 1.487 & 0.138 & H1d: Rejected \\
\hline Accessibility & .330 & 8.472 & 0.000 & $\mathrm{H}_{1 \mathrm{e}}$ : Accepted \\
\hline
\end{tabular}


$\mathrm{R}=0.750$

$\mathrm{R}^{2}=0.562$

Adjusted $\mathrm{R}^{2}=0.556$

Durbin-Watson $=1.780$

$\mathrm{F}$ value $=98.009$

Sig. $F=0.000$

Note: Significant at the 0.05 level

Consistent with above Table VI, the value of adjusted R Square is 0.556 . Hence, the result suggested that 55.6 percentage of variance was explained by this model and which is in significant level. Our regression results show that the e-banking practices has a significant positive influence on customer loyalty. Therefore $\mathrm{H}_{1}$ : e-banking practices affect customer loyalty was supported. Furthermore, content $\&$ website layout $(\beta=0.398, \mathrm{P}<0.05)$, privacy $\&$ security $(\beta=0.092, \mathrm{P}<0.05)$, and accessibility $(\beta=0.330, \mathrm{P}<0.05)$ had significant positive influence on customer loyalty, hence $\mathrm{H}_{1 \mathrm{a}}, \mathrm{H}_{1 \mathrm{c}}$, and $\mathrm{H}_{1 \mathrm{e}}$ were supported. Nevertheless, customer loyalty was not influenced by speed of delivery $(\beta=0.077, \mathrm{P}>0.05)$, and convenience $(\beta=0.066, \mathrm{P}>0.05)$, So $\mathrm{H}_{1 \mathrm{~b}}$, and $\mathrm{H}_{1 \mathrm{~d}}$ were not Supported.

\section{Discussion and Conclusion}

Our basic assumption is that e-banking practices and its sub dimensions namely; content \& website layout, speed of delivery, privacy \& security, convenience, and accessibility influence the customer loyalty on selected commercial banks in the Jaffna city. A multiple regression modeling approach was proposed as an effective method for studying the impact of e-banking practices on customer loyalty. As displayed in Table VI, the adjusted R2 is 0.556, suggesting that the five e-banking factors explain close to 56 per cent of the variance for the dimension of customer loyalty. Specifically, content \& website layout $(\beta=0.398)$ has the greatest positive and significant impact on customer loyalty. This finding suggests that banks having an attractive screen layout and design with clear and simple menus easily make the customers to engage in e- banking services. This empirical evidence has provided significant support for the e-banking literature (Al-Qeisi et al., 2014; Casaló et al., 2008; Pikkarainen et al., 2004; Poon, 2007; Sohail \& Shanmugham, 2003).

Further, privacy \& security $(\beta=0.092, \mathrm{P}<0.05)$ significantly and positively influenced on customer loyalty. This suggests that, keeping customer information private and confidential make the customers satisfied and finally loyal to the organization. As these results are consistent with the existing literature (Ahmad \& Al-Zu’bi, 2011; Amin, 2016; Casaló, Flavián, \& Guinalíu, 2007; Poon, 2007; Sheng \& Liu, 2010; Wolfinbarger \& Gilly, 2003). Moreover, accessibility in e-banking practices $(\beta=0.330, \mathrm{P}<0.05)$ significantly and positively influenced on customer loyalty. This finding suggests that, accessibility in e- banking simplifies the tasks to proceed the banking activities easily without much stress and 
frustration. Hence, this way of facilitation make customers to engage in e- banking services than the traditional mood. This finding which is consistent with that of extant literature (Casaló et al., 2008; Dolatabadi \& Pool, 2013; Liébana-Cabanillas et al., 2013; Poon, 2007; Sadeghi \& Heidarzadeh Hanzaee, 2010; Sohail \& Shanmugham, 2003).

In contrast, speed of delivery $(\beta=0.077, \mathrm{P}>0.05)$ has no significant influence on customer loyalty. Even though the speed of delivery is a key driver of customer loyalty, in our study it is proved that customer loyalty has not been statistically influenced by speed of delivery. One possible explanation to this scenario may be this dimension includes measures, such as easy to navigate the bank site due to smooth speed and speed of e-transactions flow is faster than traditional banking channels, which most banks provide in the normal course of business in the e- banking services. To this end, convenience $(\beta=0.066, \mathrm{P}>0.05)$ in the e-banking practices was not significant in predicting customer loyalty. This indicates that, the services available at anytime and anywhere are not so impressive as to guarantee a long- term customer in e- banking scenario.

\subsection{Implications}

Theoretically, the outcome of this study provides empirical evidence for how to make loyal customers to banks through e-banking. Further, this study and its findings can significantly contribute to the existing literature relating to e-banking practices and customer behavior specifically customer loyalty. Customer loyalty can be enhanced by developing a habit among the bank consumers to use the e- banking. We found that content \& website layout, privacy \& security, and accessibility were the most important factors that affect customer loyalty relating with e-banking. Therefore, managers should focus on the above mentioned dimesions to enhance the loyalty in e- banking platform.

\subsection{Limitations and Suggestions for Future Research}

In addition, this study was confined to commercial banks in jaffna city, Sri Lanka. Therefore, to better generalize the findings of this study, it need to be extented with the commercial banks in other part of the country. Further, the current study did not include all possible variables which affect customer loyalty towards e-banking practices such as fees and charges, user experience, trust in one's bank, reluctance, interactivity and perceived risk. It needs to be further enhanced with other possible independent variables which significantly influence customer loyalty. Furtherthan, researchers can examine the infuluence of mediator and moderator variables, which may create the comprehensive model.

\section{References}

Adapa, S., \& Cooksey, R. (2013). Factors affecting consumer's continued use of Internet banking: Empirical Evidence from Australia. Australasian Journal of Information Systems, 18(1).

Agarwal, R., Sambamurthy, V., \& Stair, R. M. (2000). The evolving relationship between general and specific computer self-efficacy-An empirical assessment. Information Systems Research, 11(4), 418-430. 
Ahmad, A. M. K., \& Al-Zu'bi, H. A. (2011). E-banking functionality and outcomes of customer satisfaction: an empirical investigation. International journal of marketing studies, 3(1), 50.

Ahsan, N., Abdullah, Z., Fie, D. G., \& Alam, S. S. (2009). A study of job stress on job satisfaction among university staff in Malaysia: Empirical study. European journal of social sciences, 8(1), 121-131.

Ajzen, I., \& Fishbein, M. (1975). Belief, attitude, intention and behavior: An introduction to theory and research: Reading, MA: Addison-Wesley.

Al-Alak, B. A. (2014). Impact of marketing activities on relationship quality in the Malaysian banking sector. Journal of Retailing and Consumer Services, 21(3), 347-356.

Al-Qeisi, K., Dennis, C., Alamanos, E., \& Jayawardhena, C. (2014). Website design quality and usage behavior: Unified Theory of Acceptance and Use of Technology. Journal of Business Research, 67(11), 2282-2290.

Aladwani, A. M. (2001). Online banking: a field study of drivers, development challenges, and expectations. International Journal of Information Management, 21(3), 213-225.

Alhinai, Y. S., Albadi, A., Alshihi, H., \& Al-Gharbi, K. (2013). Investigating Determinants of E-banking Adoption by Individuals: Comparing the Impact of System Characteristics and User Traits. International Review of Management and Business Research, 2(2), 371.

Amin, M. (2016). Internet banking service quality and its implication on e-customer satisfaction and e-customer loyalty. International Journal of Bank Marketing, 34(3), 280-306.

Andaleeb, S. S., Rashid, M., \& Rahman, Q. A. (2016). A model of customer-centric banking practices for corporate clients in Bangladesh. International Journal of Bank Marketing, 34(4), 458-475.

Angelakopoulos, G., \& Mihiotis, A. (2011). E-banking: challenges and opportunities in the Greek banking sector. Electronic Commerce Research, 11(3), 297-319.

Anguelov, C. E., Hilgert, M. A., \& Hogarth, J. M. (2004). US consumers and electronic banking, 1995-2003. Fed. Res. Bull., 90, 1.

Ariff, M. S. M., Yun, L. O., Zakuan, N., \& Jusoh, A. (2012). Examining dimensions of electronic service quality for internet banking services. Procedia-Social and Behavioral Sciences, 65, 854-859.

Armstrong, G., Adam, S., Denize, S., \& Kotler, P. (2014). Principles of marketing: Pearson Australia.

Auta, E. M. (2010). E-Banking in developing economy: Empirical evidence from Nigeria. Journal of applied quantitative methods, 5(2).

Bauer, H. H., Hammerschmidt, M., \& Falk, T. (2005). Measuring the quality of e-banking portals. International Journal of Bank Marketing, 23(2), 153-175.

Bruno, M. (2003). BofA's climb to the top of the on-line world. USBanker, 113(6), 24-24.

Bukhari, A. N., \& Kazi, R. (2016). CRM triggers effectiveness through Customer Selection Orientation, Business Cycle Orientation, Cross-Functional Integration and Dual Value Creation: Myth or Reality. Journal of Marketing Management, 4(1), 163-171. 
Casaló, L. V., Flavián, C., \& Guinalíu, M. (2007). The role of security, privacy, usability and reputation in the development of online banking. Online Information Review, 31(5), 583-603. Casaló, L. V., Flavián, C., \& Guinalíu, M. (2008). The role of satisfaction and website usability in developing customer loyalty and positive word-of-mouth in the e-banking services. International Journal of Bank Marketing, 26(6), 399-417.

Chau, P. Y. (2001). Influence of computer attitude and self-efficacy on IT usage behavior. Journal of Organizational and End User Computing, 13(1), 26.

Chen, S.-C. (2015). Customer value and customer loyalty: Is competition a missing link? Journal of Retailing and Consumer Services, 22, 107-116.

Chen, Y. H., \& Barnes, S. (2007). Initial trust and online buyer behaviour. Industrial Management \& Data Systems, 107(1), 21-36.

Chuttur, M. Y. (2009). Overview of the technology acceptance model: Origins, developments and future directions. Working Papers on Information Systems, 9(37), 9-37.

Creswell, J. W. (2005). Research design: Planning, conducting, and evaluating quantitative and qualitative research: Upper Saddle River, NJ: Pearson/Merrill Prentice Hall.

Daniel, E. (1999). Provision of electronic banking in the UK and the Republic of Ireland. International Journal of Bank Marketing, 17(2), 72-83.

Davis, F. D. (1989). Perceived usefulness, perceived ease of use, and user acceptance of information technology. MIS quarterly, 319-340.

Dekimpe, M. G., Steenkamp, J.-B. E., Mellens, M., \& Abeele, P. V. (1997). Decline and variability in brand loyalty. International Journal of Research in Marketing, 14(5), 405-420.

Diatmika, I. W. B., Irianto, G., \& Baridwan, Z. (2016). Determinants of Behavior Intention Of Accounting Information Systems Based Information Technology Acceptance. Imperial Journal of Interdisciplinary Research, 2(8).

Dolatabadi, H. R., \& Pool, J. K. (2013). Analysis electronic service quality through ES-Qual scale: the case study of Nowshahr hotel. Research Journal of Applied Sciences, Engineering and Technology, 5(7), 2321-2326.

Dwivedi, Y. K., Rana, N. P., Jeyaraj, A., Clement, M., \& Williams, M. D. (2017). Re-examining the Unified Theory of Acceptance and Use of Technology (UTAUT): Towards a Revised Theoretical Model. Information Systems Frontiers, 1-16.

Flavián, C., Guinalíu, M., \& Gurrea, R. (2006). The role played by perceived usability, satisfaction and consumer trust on website loyalty. Information \& Management, 43(1), 1-14.

Floh, A., \& Treiblmaier, H. (2006). What keeps the e-banking customer loyal? A multigroup analysis of the moderating role of consumer characteristics on e-loyalty in the financial service industry.

George, D., \& Mallery, M. (2003). Using SPSS for Windows step by step: A simple guide and reference.

Gerrard, P., \& Barton Cunningham, J. (2003). The diffusion of internet banking among Singapore consumers. International Journal of Bank Marketing, 21(1), 16-28.

Gerrard, P., Barton Cunningham, J., \& Devlin, J. F. (2006). Why consumers are not using internet banking: a qualitative study. Journal of Services Marketing, 20(3), 160-168. 


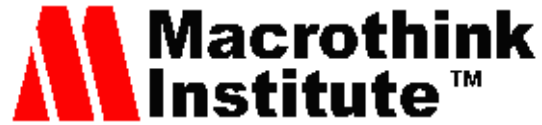

Goi, C. L. (2015). Factors influence development of e-banking in Malaysia. The Journal of Internet Banking and Commerce, 2006.

Gorgani, G. (2016). The effect of e-banking on bank customers' deposits. International Journal of Humanities and Cultural Studies (IJHCS) ISSN 2356-5926, 1(1), 2231-2246.

Hair Jr, J., Black, W., Babin, B., Anderson, R., \& Tatham, R. (2010). SEM: An introduction. Multivariate data analysis: A global perspective, 629-686.

Heppner, P. P., \& Heppner, M. J. (2004). Writing and publishing your thesis, dissertation, and research: A guide for students in the helping professions: Thomson/Brooks/Cole.

Hong, W., Thong, J. Y., \& Wai-Man Wong, K.-Y. T. (2002). Determinants of user acceptance of digital libraries: an empirical examination of individual differences and system characteristics. Journal of Management Information Systems, 18(3), 97-124.

Jayawardhena, C., \& Foley, P. (2000). Changes in the banking sector-the case of Internet banking in the UK. Internet Research, 10(1), 19-31.

Joanes, D., \& Gill, C. (1998). Comparing measures of sample skewness and kurtosis. Journal of the Royal Statistical Society: Series D (The Statistician), 47(1), 183-189.

Johnson, R. D., \& Marakas, G. M. (2000a). Research report: the role of behavioral modeling in computer skills acquisition: toward refinement of the model. Information Systems Research, 11(4), 402-417.

Johnson, R. D., \& Marakas, G. M. (2000b). The role of behavioral modeling in computer skills acquisition: Toward refinement of the model. Information Systems Research, 11(4), 402-417.

Karjaluoto, H., Mattila, M., \& Pento, T. (2002). Factors underlying attitude formation towards online banking in Finland. International Journal of Bank Marketing, 20(6), 261-272. Katsikas, S. K., Lopez, J., \& Pernul, G. (2005). Trust, privacy and security in e-business: Requirements and solutions. Paper presented at the Panhellenic Conference on Informatics.

Kaur, N., \& Kiran, R. (2015). E-banking service quality and customer loyalty: Changing dynamics of public, private and foreign bank consumers in India. Global Business and Management Research, 7(1), 74.

Kazi, A. K. (2013). An empirical study of factors influencing adoption of Internet banking among students of higher education: Evidence from Pakistan. International Journal of Finance \& Banking Studies, 2(2), 87.

Keating, B., Rugimbana, R., \& Quazi, A. (2003). Differentiating between service quality and relationship quality in cyberspace. Managing Service Quality: An International Journal, 13(3), 217-232.

Kheng, L. L., Mahamad, O., Ramayah, T., \& Mosahab, R. (2010). The impact of service quality on customer loyalty: A study of banks in Penang, Malaysia. International Journal of Marketing Studies, 2(2), 57.

Kim, H.-Y. (2013). Statistical notes for clinical researchers: assessing normal distribution (2) using skewness and kurtosis. Restorative Dentistry \& Endodontics, 38(1), 52-54.

Kleinbaum, D. G., Kupper, L. L., \& Muller, K. E. (1988). Applied Regression Analysis and Other Multivariate Methods: Student's Partial Solutions Manual: PWS-Kent. 
Kolsaker, A., \& Payne, C. (2002). Engendering trust in e-commerce: a study of gender-based concerns. Marketing Intelligence \& Planning, 20(4), 206-214.

Kotler, P., \& Armstrong, G. (2013). Principles of Marketing (16th Global Edition).

Lallmahamood, M. (2007). An Examination of Individual's Perceived Security and Privacy of the Internet in Malaysia and the Influence of this on their Intention to Use E-commerce: Using an Extension of the Technology Acceptance Model. Journal of Internet Banking and Commerce, 12(3), 1.

Lassar, W. M., Manolis, C., \& Lassar, S. S. (2005). The relationship between consumer innovativeness, personal characteristics, and online banking adoption. International Journal of Bank Marketing, 23(2), 176-199.

Lederer, A. L., Mirchandani, D. A., \& Sims, K. (2001). The search for strategic advantage from the World Wide Web. International Journal of Electronic Commerce, 5(4), 117-133.

Liao, Z., \& Cheung, M. T. (2002). Internet-based e-banking and consumer attitudes: an empirical study. Information \& Management, 39(4), 283-295.

Lichtenstein, S., \& Williamson, K. (2006). Understanding consumer adoption of internet banking: an interpretive study in the Australian banking context. Journal of Electronic Commerce Research, 7(2), 50.

Liébana-Cabanillas, F., Munoz-Leiva, F., \& Rejón-Guardia, F. (2013). The determinants of satisfaction with e-banking. Industrial Management \& Data Systems, 113(5), 750-767.

Lin, H.-H., \& Wang, Y.-S. (2006). An examination of the determinants of customer loyalty in mobile commerce contexts. Information \& Management, 43(3), 271-282.

Luarn, P., \& Lin, H.-H. (2003). A customer loyalty model for e-service context. J. Electron. Commerce Res., 4(4), 156-167.

Martins, C., Oliveira, T., \& Popovič, A. (2014). Understanding the Internet banking adoption: A unified theory of acceptance and use of technology and perceived risk application. International Journal of Information Management, 34(1), 1-13.

Masoud, E., \& AbuTaqa, H. (2017). Factors Affecting Customers' Adoption of E-Banking Services in Jordan. Information Resources Management Journal (IRMJ), 30(2), 44-60.

Mobarek, A. (2007). E-banking practices and customer satisfaction-a case study in botswana. Mohsin Butt, M., \& Aftab, M. (2013). Incorporating attitude towards Halal banking in an integrated service quality, satisfaction, trust and loyalty model in online Islamic banking context. International Journal of Bank Marketing, 31(1), 6-23.

Mukherjee, A., \& Nath, P. (2003). A model of trust in online relationship banking. International journal of bank marketing, 21(1), 5-15.

Narayanasamy, K., Rasiah, D., \& Tan, T. M. (2011). The adoption and concerns of e-finance in Malaysia. Electronic Commerce Research, 11(4), 383.

Nudurupati, S. S., Tebboune, S., \& Hardman, J. (2016). Contemporary performance measurement and management (PMM) in digital economies. Production Planning \& Control, 27(3), 226-235.

Nupur, J. M. (2010). E-banking and customers' satisfaction in Bangladesh: An analysis. International Review of Business Research Papers, 6(4), 145-156. 
Oly Ndubisi, N. (2007). Relationship marketing and customer loyalty. Marketing Intelligence \& Planning, 25(1), 98-106.

Pallant, J. (2007). SPSS survival manual: A step-by-step guide to data analysis using SPSS version 15. Nova Iorque: McGraw Hill.

Park, E., Baek, S., Ohm, J., \& Chang, H. J. (2014). Determinants of player acceptance of mobile social network games: An application of extended technology acceptance model. Telematics and Informatics, 31(1), 3-15.

Petzer, D. J., Petzer, D. J., De Meyer-Heydenrych, C. F., De Meyer-Heydenrych, C. F., Svensson, G., \& Svensson, G. (2017). Perceived justice, service satisfaction and behavior intentions following service recovery efforts in a South African retail banking context. International Journal of Bank Marketing, 35(2), 241-253.

Pikkarainen, T., Pikkarainen, K., Karjaluoto, H., \& Pahnila, S. (2004). Consumer acceptance of online banking: an extension of the technology acceptance model. Internet research, 14(3), 224-235.

Polasik, M., \& Piotr Wisniewski, T. (2009). Empirical analysis of internet banking adoption in Poland. International Journal of Bank Marketing, 27(1), 32-52.

Poon, W.-C. (2007). Users' adoption of e-banking services: the Malaysian perspective. Journal of Business \& Industrial Marketing, 23(1), 59-69.

Poon, W.-C., Yong, G.-F. D., \& Lam, W.-H. P. (2008). An insight into the attributes influencing the acceptance of Internet banking: The consumers' perspective. International Journal of Services and Standards, 5(1), 81-94.

Ramsaran, C. (2003). Online banking comes of age. Bank Systems \& Technology, 40(11), 2-30.

Reichheld, F. F., \& Sasser, W. E. (1990). Zero Defeofions: Quoliiy Comes To Services.

Ribbink, D., Van Riel, A. C., Liljander, V., \& Streukens, S. (2004). Comfort your online customer: quality, trust and loyalty on the internet. Managing Service Quality: An International Journal, 14(6), 446-456.

Rotchanakitumnuai, S., \& Speece, M. (2003). Barriers to Internet banking adoption: a qualitative study among corporate customers in Thailand. International Journal of Bank Marketing, 21(6/7), 312-323.

Rotchanakitumnuai, S., \& Speece, M. (2004). Corporate customer perspectives on business value of Thai internet banking services.

Sadeghi, T., \& Heidarzadeh Hanzaee, K. (2010). Customer satisfaction factors (CSFs) with online banking services in an Islamic country: IR Iran. Journal of Islamic Marketing, 1(3), 249-267.

Santhapparaj, A. S., \& Alam, S. S. (2005). Job satisfaction among academic staff in private universities in Malaysia. Journal of Social Sciences, 1(2), 72-76.

Santos, J. (2003). E-service quality: a model of virtual service quality dimensions. Managing Service Quality: An International Journal, 13(3), 233-246. 
Sanzo, M. a. J., Santos, M. a. L., Vázquez, R., \& Álvarez, L. I. (2003). The effect of market orientation on buyer-seller relationship satisfaction. Industrial Marketing Management, 32(4), 327-345.

Sarel, D., \& Marmorstein, H. (2003). Marketing online banking services: The voice of the customer. Journal of Financial Services Marketing, 8(2), 106-118.

Shahriari, S. (2014). Effective factors on loyalty of e-banking customers. International Journal, 2(3).

Sheng, T., \& Liu, C. (2010). An empirical study on the effect of e-service quality on online customer satisfaction and loyalty. Nankai Business Review International, 1(3), 273-283.

Siu, N. Y.-M., \& Mou, J. C.-W. (2005). Measuring service quality in internet banking: the case of Hong Kong. Journal of International Consumer Marketing, 17(4), 99-116.

Sohail, M. S., \& Shanmugham, B. (2003). E-banking and customer preferences in Malaysia: An empirical investigation. Information sciences, 150(3), 207-217.

Srinivasan, S. S., Anderson, R., \& Ponnavolu, K. (2002). Customer loyalty in e-commerce: an exploration of its antecedents and consequences. Journal of retailing, 78(1), 41-50.

Tabachnick, B., \& Fidell, L. (2007). Using multivariate statistics”. Boston: Pearson International Edition.

Taleghani, M., Gilaninia, S., \& Mousavian, S. J. (2011). The role of relationship marketing in customer orientation process in the banking industry with focus on loyalty (Case study: Banking industry of Iran). International Journal of Business and Social Science, 2(19).

Tan, M., \& Teo, T. S. (2000). Factors influencing the adoption of Internet banking. Journal of the AIS, 1(1es), 5.

Thakur, R. (2014). What keeps mobile banking customers loyal? International Journal of Bank Marketing, 32(7), 628-646.

Toufaily, E., Ricard, L., \& Perrien, J. (2013). Customer loyalty to a commercial website: Descriptive meta-analysis of the empirical literature and proposal of an integrative model. Journal of Business Research, 66(9), 1436-1447.

Usman, U., \& Usman, F. I. (2012). International Journal of Arts \& Education Research.

Venkatesh, V., \& Davis, F. D. (1996). A model of the antecedents of perceived ease of use: Development and test. Decision Sciences, 27(3), 451-481.

Venkatesh, V., \& Davis, F. D. (2000). A theoretical extension of the technology acceptance model: Four longitudinal field studies. Management Science, 46(2), 186-204.

Vijayan, P., \& Shanmugam, B. (2015). Service quality evaluation of internet banking in Malaysia. The Journal of Internet Banking and Commerce, 2003.

Wan, W. W., Luk, C.-L., \& Chow, C. W. (2005). Customers' adoption of banking channels in Hong Kong. International Journal of Bank Marketing, 23(3), 255-272.

Wang, Y.-S., Wang, Y.-M., Lin, H.-H., \& Tang, T.-I. (2003). Determinants of user acceptance of Internet banking: an empirical study. International Journal of Service Industry Management, 14(5), 501-519.

Wolfinbarger, M., \& Gilly, M. C. (2003). eTailQ: dimensionalizing, measuring and predicting etail quality. Journal of Retailing, 79(3), 183-198. 
Wu, J.-J., \& Chang, Y.-S. (2005). Towards understanding members' interactivity, trust, and flow in online travel community. Industrial Management \& Data Systems, 105(7), 937-954.

Yoon, H. S., \& Steege, L. M. B. (2013). Development of a quantitative model of the impact of customers' personality and perceptions on Internet banking use. Computers in Human Behavior, 29(3), 1133-1141.

Yu, T.-K., \& Fang, K. (2009). Measuring the post-adoption customer perception of mobile banking services. Cyberpsychology \& Behavior, 12(1), 33-35.

Yuen, E. F., \& Chan, S. S. (2010). The effect of retail service quality and product quality on customer loyalty. Journal of Database Marketing \& Customer Strategy Management, 17(3-4), 222-240.

\section{Copyright Disclaimer}

Copyright for this article is retained by the author(s), with first publication rights granted to the journal.

This is an open-access article distributed under the terms and conditions of the Creative Commons Attribution license (http://creativecommons.org/licenses/by/3.0/). 